\title{
Post-Crisis Economic and Social Policy: Some Thoughts on Structural Reforms 2.0.
}

Philomila Tsoukala

Georgetown University Law Center, pt96@law.georgetown.edu

This paper can be downloaded free of charge from:

https://scholarship.law.georgetown.edu/facpub/2100

https://ssrn.com/abstract=3273562

Post-Crisis Economic and Social Policy: Some Thoughts on Structural Reforms 2.0., in EU Law in Populist Times: Crises and Prospects (Francesca Bignami ed., Cambridge: Cambridge University Press forthcoming).

This open-access article is brought to you by the Georgetown Law Library. Posted with permission of the author. Follow this and additional works at: https://scholarship.law.georgetown.edu/facpub

Part of the Comparative and Foreign Law Commons, European Law Commons, and the Public Economics Commons 


\title{
Post-Crisis Economic and Social Policy: Some Thoughts on Structural Reforms 2.0.
}

\author{
Philomila Tsoukala
}

Managing the euro crisis has been a process of institutional transformation for the EU. The European Semester has emerged as a powerful tool for economic policy coordination between the Member States. Beyond the new enforcement tools that the Semester affords the Commission and Council in case of non-compliance with country-specific recommendations, the management of the crisis has given the Commission experience in structural reforms. The Commission now regularly uses this experience in formulating its yearly country-specific recommendations to Member States. Far from a stalwart of untethered neoliberalism, the Commission has been fashioning itself as the manager with a human face, the institution that understands both the structural reform requirements for a global economy, and the special need for strong social institutions that could shield European citizens from the worst of the shocks provoked by globalized markets. Hence the name, "Structural Reforms 2.0," per the Juncker Commission. ${ }^{1}$

In this chapter, I review the Commission's emerging structural reform "know-how," as represented in its latest reflection papers and European Semester documents. The European Commission seems to have drawn from its experience in managing loan conditionality for debtor countries like Greece, Portugal, and Ireland, in order to come up with the set of structural reforms that it considers necessary for any country to thrive within the context of the euro. At the same time, it has taken on board the critiques of structural reforms that point to the potentially negative short-term effects of structural adjustment. Thus, the Commission seems to have fully embraced the idea of the EU as a soft alternative to unfettered globalization and has taken it upon itself to monitor certain aspects of the welfare state in Member States.

The Commission's recommendations, however, while presented in the mode of technocratic expertise, entail deeply political choices in almost every imaginable regulatory field. Despite constant assurances that there is no "one-size fits all" model for structural reforms, what is shaping up through the European Semester is effectively a list of desirable reforms - a set menu of options - which the Commission now openly characterizes as "EU best practices." If applied, they would provoke deep restructurings and adjustments of national political economies with winners and losers to boot. These demands for deep restructurings are couched in a language of technical adjustment and fine-tuning that does not do justice to the qualitative reform required of the Member States nor to the substantive trade-offs between market efficiency and social fairness that only a democratic process can legitimize. Contrary to some observers, I conclude that the inclusion of social policy goals into the European Semester can be an indication of both the success of socially minded actors in influencing the content of macroeconomic governance, and of the success of

\footnotetext{
${ }^{1}$ Pierre Moscovici, Commissioner European Commission, Speech Structural Reforms 2.0: For a Stronger and More Inclusive Recovery, SPEECH/16/2124 (June 9, 2016).
} 
market-minded actors in adapting to demands for "social fairness" in macroeconomic governance without ceding much space in terms of the kinds of reforms required. Much of this "socialization" of the European Semester will depend on how the rest of the management of the common currency evolves.

\section{Background to the Coordination of Member State Economic Policies}

The Maastricht Treaty infamously introduced the idea of the common currency without establishing a common EU-wide economic policy. At the insistence of Germany, Member States adopted the Stability and Growth Pact (SGP), which was meant to commit Member States to budgetary and fiscal restraint. ${ }^{2}$ More specifically, Member States agreed to maintain their budget deficit to under $3 \%$ of their GDP and their debt to under $60 \%$ of their GDP. The Treaties specified a mechanism of multilateral surveillance of state economic policies, aimed at ensuring respect of the SGP, the so-called 'preventive arm' of the SGP. More specifically, the Council, on the basis of a Commission proposal would set broad guidelines on economic policy that the Member States should respect. It would then monitor Member State adherence to those guidelines based on reports submitted by the Commission. The Council could address specific recommendations to Member States if it thought that the Member State's economic policy deviated from the broad guidelines. ${ }^{3}$

In addition to the 'preventive arm' of this process of multilateral surveillance, the Treaties provided for a 'corrective arm,' which was meant to induce compliance with budgetary and debt limits. The Commission would decide whether a specific Member State was in violation of the budget and debt limit criteria of the SGP. In other words, it would decide whether there was an excessive deficit or a Member State was close to running an excessive deficit and make a relevant recommendation to the Council. The Council would then address recommendations to the Member State in question, suggesting measures to bring the deficit situation under control. The specific efforts of the Member State to correct the deficit would be monitored. If the Member State failed to respond to Council recommendations, the Council could resort to a number of more coercive strategies such as requiring the Member State to make a non-interest bearing deposit with the Union until the problem was corrected, or, in the last resort, impose fines of an "appropriate size.",

\footnotetext{
2 The legal basis for the SGP can be found in the Treaties (now Articles 121 and 126 of the Consolidated Version of the Treaty on the Functioning of the European Union, October 26, 2012, 2012 O.J. (C 326) 47 [hereinafter TFEU]). Its content was specified in two Regulations and one Council Resolution. See Council Regulation 1466/97, On the Strengthening of the Surveillance of Budgetary Positions and the Surveillance and Coordination of Economic Policies, 1997 O.J. (L 209) 1; Council Regulation 1467/97, On Speeding up and Clarifying the Implementation of the Excessive Deficit Procedure, 1997 O.J. (L 209) 6; Council Resolution, On the Stability and Growth Pact, 1997 O.J. (C 236) 1. For the particularly important role that the governments of Germany and the Netherlands played in the adoption of the SGP see Martin Heipertz and Amy Verdun, "The Dog that Would Never Bite? What We Can Learn from the Origins of the Stability and Growth Pact," Journal of European Public Policy 11, no. 5 (2004): 756-80.

${ }^{3}$ Article 121 TFEU.

${ }^{4}$ Article 126 TFEU.
} 
The SGP and its preventive and corrective arms were fiercely debated in the relevant literature with critics arguing both that the pact was too 'inflexible' in imposing a numerically fixed limit to budget and debt deficits, and that it was too 'soft' or 'ineffective.' 5 The implementation of the multilateral surveillance seemed to vindicate the latter critique. Between 2001-2003, several Member States were found to be in violation of the SGP; however, no sanctions were imposed, and after a vote from a divided Council, the excessive deficit procedure was put in abeyance for France and Germany, despite the fact that neither state had complied. ${ }^{6}$ The SGP Regulations were reformed in 2005, introducing further flexibility in the application of the excessive deficit procedure. ${ }^{7}$

The ideological tides started changing against flexibility and in favor of stricter enforcement after the Greek crisis, which transformed into a euro crisis, starting in 2010. Whatever one may think about the origins and causes of the crisis, there was little doubt that Greece's debt burden had exposed it to the pressures of international markets, which in turn had affected other Eurozone Member States. This reinforced the consensus around the need for stricter oversight of Member State economic policy by the EU. This translated into a series of measures embodied in the so-called 'Six Pack' and 'Two Pack' adopted between 2011 and 2013. ${ }^{8}$ In addition, twenty-five Member States adopted the Treaty on Stability, Coordination, and Governance in 2012, which commits them to a balanced budget. 9

Perhaps the most important change brought about by the post-2010 package of new measures is the creation of the European Semester, described by the Council as "a cycle of economic and fiscal policy coordination" aimed at ensuring "convergence and stability in the EU," "sound public finances" and fostering of economic growth. ${ }^{10}$ Each year in December, the Commission analyzes the economic situation and publishes an "Annual Growth Survey" (AGS) in preparation for the upcoming European Semester. Between January and July, the Council reviews the AGS and after obtaining the opinion of the European Parliament adopts its conclusions on the AGS. The European Council then proposes guidelines based on this process. The second phase of the European Semester includes a review of the specific policies of individual Member States. Each Member State

\footnotetext{
${ }^{5}$ See generally Heipertz and Verdun, "The Dog that Would Never Bite?"; Jakob de Haan et al., "Why Has the Stability and Growth Pact Failed?," International Finance 7, no. 3 (2004): 235-60; Jürgen von Hagen, "Fiscal Discipline and Growth in Euroland: Experiences with the Stability and Growth Pact." Working Paper no. B 06-2003, ZEI, Center for European Integrations, 2003, 1-35.

${ }^{6}$ See generally Heipertz and Verdun, "The Dog that Would Never Bite?," 765.

7 Jean-Victor Louis, "The Review of the Stability and Growth Pact," Common Market Law Review 43, no. 1 (2006): 85-106.

${ }^{8}$ The Six Pack consisted of five Regulations and one Directive, while the Two Pack included two Regulations. The most important reforms included an intensification of the ex-ante surveillance of economic policy and the introduction of the potential for the imposition of ex-post fines in cases of violation. See Council of the EU, "European Semester: A Guide to the Main Rules and Documents," November 10, 2017, http://www.consilium.europa.eu/en/policies/european-semester/european-semester-key-rules-and-

documents/.

${ }^{9}$ Daniel Gros, "The Treaty on Stability, Coordination and Governance in the Economic and Monetary Union (aka Fiscal Compact).” Working Document, Centre for European Political Studies, March 8, 2012.

${ }^{10}$ Council of the EU, "European Semester: Overview," March 14, 2018, http://www.consilium.europa.eu/en/policies/european-semester/.
} 
submits a report on its proposed policies and budget. The Commission then publishes country-specific recommendations on the basis its own review, which are then adopted by the Council. Member States then take these recommendations into consideration before discussing their national budgets.

Running parallel to the review of economic policies, the European Semester also includes a review of each Member State's macroeconomic position. This process is the heir to the preventive and corrective arms of the SGP. A review of a certain number of macroeconomic indicators, result in a judgment about whether a Member State is in macroeconomic imbalance. The Commission incorporates the macroeconomic imbalance analysis in its country-specific recommendations and the Council in turn adopts them. Member States are expected to comply with those recommendations in deciding their national budgets. The barrage of measures included in the Six Pack and Two Pack after the 2010 crisis include the possibility for the automatic imposition of fines in cases of Member State non-compliance with the country-specific recommendations. Thus far, this possibility has only been mobilized once, against Spain, on the rather technical basis that the statistics provided by one of its provinces were inaccurate. ${ }^{11}$

The European Semester has imposed a certain European "timing" to national budgetary processes that would otherwise differ widely from one another. As Nicolas Jabko observes in his contribution to this volume, this shift in timing is of symbolic importance, signaling a new, "practice of sovereignty," and one that accepts more intrusion on national budgets from the EU level. ${ }^{12}$ The European Semester has also brought about a renewed emphasis on structural reforms, imagined as the main way in which Member States can alter basic features of their economic performance with the goal of achieving better growth and "convergence" at the EU level. The structural reform recommendations of the Council, as proposed by the Commission, can give us a picture of the kind of economy imagined as ideal by EU experts. A careful reading of the latest round of such recommendations allows us to observe the emergence of certain types of structural reforms as desirable for most Member States, as well as a certain degree of carry-over from the 'know-how' the Commission developed in managing the bail-out agreements of Greece, Ireland, and Portugal.

While the effectiveness of the European Semester has been highly doubted in the relevant literature, I believe it still carries a great deal of weight, especially since it seems to have solidified the Commission's claimed expertise in structural reforms, which in turns is shaping what the Commission has referred to as "European best practices." 13 The acceptance of these proposed structural reforms may differ from Member State to Member State depending on many factors, the most important of which perhaps is the Member

\footnotetext{
${ }^{11}$ See discussion infra.

${ }^{12}$ Nicolas Jabko, "Politicized Integration: The Case of the Eurozone Crisis," this volume.

${ }^{13}$ Memorandum of Understanding Between the European Commission Acting on Behalf of the European Stability Mechanism and the Hellenic Republic and the Bank of Greece (August 2015), 5, https://ec.europa.eu/info/sites/info/files/01_mou_20150811_en1.pdf (“Greece will design and implement a wide range of reforms in labour markets and product markets (including energy) that not only ensure full compliance with EU requirements, but which also aim at achieving European best practices”).
} 
State's fiscal and economic position. ${ }^{14}$ The other important innovation post-crisis is the creation of the European Stability Mechanism (ESM), whose funds could potentially be accessed by Member States in distress, only upon condition of compliance, however, with proposed reforms, which are designed by the European Commission, in coordination with the European Central Bank and, where needed, the International Monetary Fund. ${ }^{15}$ Thus, Member States that may feel more exposed to the vagaries of international markets because of their fiscal positions, will experience more pressure to comply with proposed structural reform recommendations. Unsurprisingly, Germany has felt no impulse to comply with the European Semester recommendations on its persistent surplus, which is thought to impede the adjustment of debtor Member States. ${ }^{16}$

Finally, the corpus of Commission-endorsed structural reforms is currently one of the most important sites of discursive contestation between those who would like to see the EU take a more 'social' turn and those who believe that European welfarism lies at the heart of the EU's current economic woes. The twists and turns of the "social," therefore, within the European Semester are worth following and analyzing.

\section{From One-Size-Fits-All to Adaptable Convergence?}

The European Commission has produced a voluminous literature in the last eight years in the course of managing the euro crisis and the loan agreements between Eurozone members and debtor countries. ${ }^{17}$ In addition, it now has several years of European Semester

\footnotetext{
${ }^{14}$ Mark Hallerberg et al., "How Effective and Legitimate is the European Semester? Increasing the Role of the European Parliament." Bruegel Working Paper no. 2011/09, September 2011, 23 ("As to its effectiveness, the preliminary evidence is that countries have adapted differently to the new procedures depending on whether they are 'old' or 'new' Member States; if their economic interests lie exclusively with the EU or not; and if they have strong or weak national fiscal frameworks.")

15 "Lending toolkit," European Stability Mechanism website, last visited October 24, 2018, https://www.esm.europa.eu/assistance/lending-toolkit. For scholarly treatment of the European Commission's role in the ESM see Michael W. Bauer and Stefan Becker, "The Unexpected Winner of the Crisis: The European Commission's Strengthened Role in Economic Governance," Journal of European Integration 36, no. 3 (2014): 213-29.

${ }^{16}$ European Commission Staff Working Document: Country Report Germany 2017, SWD (2017) 71 final (February 22, 2017), 1-2.

${ }^{17}$ Greece has received financial assistance on three different occasions. The first bailout agreement in 2010 was between Greece, Eurozone Member States and the International Monetary Fund, as was the second one in 2012. In 2015 Greece received a financial assistance package from the recently created European Stability Mechanism. The European Commission has been in charge of supervising implementation of all these programs on behalf of the Eurozone creditors. Besides the basic agreement on the conditionality of these programs, which was encapsulated in Memoranda of Understanding (MoU), each one of these programs had several rounds of review with voluminous reports on compliance. For a comprehensive list of all the major publications produced in the process of this supervision, see "Financial Assistance to Greece," European Commission website, last visited July 6, 2018, https://ec.europa.eu/info/business-economy-euro/economicand-fiscal-policy-coordination/eu-financial-assistance/which-eu-countries-have-receivedassistance/financial-assistance-greece en\#financial-assistance-programmes. For the documents generated in the case of the Irish bailout, see "Financial Assistance to Ireland," European Commission website, last visited July 6, 2018, https://ec.europa.eu/info/business-economy-euro/economic-and-fiscal-policy-coordination/eufinancial-assistance/which-eu-countries-have-received-assistance/financial-assistance-ireland_en; for Portugal, see "Financial Assistance to Portugal," European Commission website, last visited July 6, 2018,
} 
coordination under its belt. ${ }^{18}$ The country-specific recommendations for the European Semester allow us to draw conclusions about the kinds of reforms the Commission believes are needed for successful economic governance within the EMU. Tracing the evolution of recommended reforms to their latest iteration suggests that far from treating Greece and other bailout countries as an extreme and rare case of macroeconomic instability, the Commission is drawing conclusions about desirable reforms for potentially every member of the Eurozone from its experience as a manager of bailout conditionality. ${ }^{19}$

The first thing to note is that the Commission has fully embraced the idea that there were structural defects in the design of the euro that led to a patchwork institutional response in the panicked, emergency follow-up to the crisis. ${ }^{20}$ In fact, the Commission goes as far as to acknowledge theories of sudden stoppage of liquidity in an incomplete monetary union, that is in a union without a lender of last resort. ${ }^{21}$ However, it steers clear of blaming the joining together of really disparate economies under one currency as a culprit, which is what theories of the Eurozone as a non-optimal currency area have tended to do. ${ }^{22}$ Instead, the Commission points a finger to a combination of "pre-crisis imbalances" in Member States and a faulty institutional set-up in the Economic and Monetary Union (EMU), especially as regards supervision of the banking sector and guarantees that could function as a backstop in a liquidity crisis. ${ }^{23}$ This story of coproduction of the crisis then allows the Commission to emphasize that the reforms

https://ec.europa.eu/info/business-economy-euro/economic-and-fiscal-policy-coordination/eu-financialassistance/which-eu-countries-have-received-assistance/financial-assistance-portugal_en; for the case of Cyprus's bailout see "Financial Assistance to Cyprus," European Commission website, last visited July 6, 2018, https://ec.europa.eu/info/business-economy-euro/economic-and-fiscal-policy-coordination/eufinancial-assistance/which-eu-countries-have-received-assistance/financial-assistance-cyprus_en.

18 The first round of the European Semester took place in 2011. See European Commission Memorandum MEMO/11/14, European Semester: A New Architecture for the New EU Economic Governance-Q\&A (January 12, 2011).

${ }^{19}$ Institutionally, this is also exemplified in the transformation of the initially country-specific "Task Force for Greece" into the "Structural Reform Support Program." The Task Force for Greece, staffed by a mix of Commission employees and Greek civil servants, was meant to provide technical assistance to the Greek state in its structural reform efforts and expedite the channeling and use of EU structural funds in the country. See José Manuel Durão Barroso, President of the European Commission, European Renewal-State of the Union Address 2011, SPEECH/11/607 (September 28, 2011). It seems to have inspired the newly established "Structural Reform Support Service" designed "to support Member States in the preparation, design and implementation of institutional, structural and administrative reforms." See European Commission Press Release IP/18/4143, Commission Provides Support for a Further 32 Reform Projects in Greece (June 13, 2018). The new service places special emphasis on projects that improve governance, such as judicial reform and anti-corruption. See "Structural Reform Support Service," European Commission website, last visited July $\quad 6, \quad 2018, \quad$ https://ec.europa.eu/info/funding-tenders/funding-opportunities/fundingprogrammes/overview-funding-programmes/structural-reform-support-programme-srsp_en.

${ }^{20}$ Commission Reflection Paper on the Deepening of the Economic and Monetary Union, COM (2017) 291 (May 31, 2017), 9 ("shortcomings in the way the EMU responds to major shocks"); Commission Reflection Paper, COM (2017) 291, 17 ("the institutional architecture of the EMU is a mixed system...; many new rules or bodies were established in an ad hoc manner over time, often in response to emergencies").

21 Commission Reflection Paper, COM (2017) 291, 9 ("sudden stop in capital flows exposed the unsustainable debt and competitiveness gaps that had accumulated over time"). For an overview of the way in which a sudden stop in the flow of credit can transform a liquidity crisis into a solvency crisis, see Paul De Grauwe, "Managing a Fragile Eurozone," CESifo Forum 2 (Summer 2011): 40.

${ }^{22}$ Paul De Grauwe, Economics of Monetary Union 12th ed. (Oxford: Oxford University Press, 2018), 24-54.

${ }^{23}$ Commission Reflection Paper, COM (2017) 291, 9. 
necessary for fixing the institutional gaps at EU level are well underway, but since they are incomplete Member States should hurry to undergo the necessary reforms in order to avoid the production of further imbalances.

During the first years of crisis management the Commission insisted on competitiveness gaps between Member States as a causal factor in the production of the crisis, and therefore insisted on recommending reducing labor costs to improve competitiveness. ${ }^{24}$ This strategy may very well have been one of the few tools available for inducing an adjustment in indebted Member States without the availability of a devaluation, but competitiveness in and of itself figured prominently as a goal in the first few years of the post-crisis European Semester. ${ }^{25}$ While competitiveness still figures in many of its country-specific recommendations, there seems to be new emphasis on the existence of persistent divergences between Member State in the post-crisis recovery and an appreciation of the negative effects of such divergences beyond the economy:

wide gaps in growth...opened between countries and the others, with significant social and political costs. ${ }^{26}$

The Commission attributes these divergences to pre-existing country-specific weaknesses, which were hidden through the pre-crisis credit bubble - and this is as close as the Commission comes to acknowledging a contribution of the currency itself to the crisis. ${ }^{27}$ Despite the fact that the Commission recognizes the pre-crisis economic convergence to be partly an artifact of the credit bubble illusion, its plans are geared towards producing the institutional conditions that will lead to "re-convergence." 28 Thus, it considers divergence between European economies bad for the overall project of European integration, especially in the current conditions of an institutional halfway house, where monetary policy has been devolved upwards to the EU, while economic policy remains under national control subject to European Semester coordination. ${ }^{29}$

This brings us to the Commission's idea of what needs to be done by every Eurozone Member State - not just the debtor states. The general idea is "structural reforms to modernise economies and make them more resilient to shocks." 30 This is judged necessary as despite institutional progress the structure of the EMU remains incomplete and it is

${ }^{24}$ Commission Annual Growth Survey: Advancing the EU's Comprehensive Response to the Crisis, COM (2011) 11 final (January 12, 2011), 2 ("price and cost competitiveness remain problematic...the EU needs to use this crisis to address decisively the issue of its global competitiveness").

${ }^{25}$ Commission Annual Growth Survey, COM (2011) 11 final; Commission Annual Growth Survey 2012, COM (2011) 815 final (November 23, 2011), 3; Commission Annual Growth Survey 2013, COM (2012) 750 final (November 28, 2012), 3; Commission Annual Growth Survey 2014, COM (2013) 800 final (November 13, 2013), 3.

${ }^{26}$ Commission Reflection Paper, COM (2017) 291, 10.

${ }^{27}$ Commission Reflection Paper, 9, 12.

${ }^{28}$ Commission Reflection Paper, 12.

${ }^{29}$ Commission Reflection Paper, 7 ("As robust as it is today, the EMU remains incomplete. The "Monetary" pillar of the EMU is well developed, as illustrated by the role of the European Central Bank (ECB). However, the "Economic" component is lagging behind, with less integration at EU level hampering its ability to support fully the monetary policy and national economic policies").

${ }^{30}$ Commission Reflection Paper, 13. 
therefore crucially important for each Member State to have strong capacity to adapt to a potential future external shock. Thus, in the Commission's view converging towards "more resilient economic and social structures" should be the goal for everyone. ${ }^{31}$

Reaffirming its belief in the idea that the Single Market is a strong engine for convergence between European economies, the Commission prioritizes a deepening of the Single Market as the first step in the direction of re-convergence. ${ }^{32}$ The second step in the same process is a stronger economic coordination through the European Semester. There, the Commission envisages a more "binding convergence process" 33 that would focus substantively on:

quality of public spending; investment in education and training; embracing more open and more competitive products and services markets, and creating fair and efficient tax and benefit systems. ${ }^{34}$

A minimum of social standards should also be included in this convergence process and the entire enterprise should be reinforced with tighter surveillance mechanisms, according to the Commission. ${ }^{35}$ The real bite behind the monitoring of the convergence process seems to be the newly created link between progress on structural reforms and access to EU structural funds. More specifically, in order to access the funds for projects co-financed by the European Structural and Investment Funds (ESI) national governments need to address the country-specific recommendations addressed to them at the end of the European Semester. ${ }^{36}$ In its proposals on how to further deepen the EMU, the Commission proposes an outright shift towards imposing reforms as conditionality for accessing ESI funds in the future. ${ }^{37}$

From a substantive perspective, the Commission has been working on better defining the scope of desirable structural reforms over the past eight years. In his speech on structural reforms, Commissioner Moscovici recently provided some more details as to the elements of structural reforms now considered necessary for all Member States. ${ }^{38}$ According to Moscovici, the "key word for structural reforms 2.0 is productivity." This implies deep restructuring of education and vocational training systems and it also requires continued emphasis on reforms of welfare regimes towards "flexicurity.",39

${ }^{31}$ Commission Reflection Paper, 23.

${ }^{32}$ Commission Reflection Paper, 24.

${ }^{33}$ Commission Reflection Paper, 24.

${ }^{34}$ Commission Reflection Paper, 24.

${ }^{35}$ Commission Reflection Paper, 24.

${ }^{36}$ Commission Reflection Paper, 25.

${ }^{37}$ Commission Reflection Paper, 25.

${ }^{38}$ Moscovici, SPEECH/16/2124.

${ }^{39}$ Moscovici, SPEECH/16/2124. Flexicurity combines the concepts of security and flexibility and has been long considered by the Commission as the ideal model for European welfarism. The idea is to treat the labor market as the main engine of both growth for the country and income security for workers. A country that adopts a flexicurity model of welfare, would invest money in re-training and re-skilling unemployed workers so that they can return to the labor market as soon as possible. The flexicurity model is thought to stand in contrast with other models of welfarism that seek to simply provide a safe floor for workers' incomes and that are increasingly believed to discourage return to labor markets. See Ton Wilthagen and Frank Tros, "The 
Specific examples of how the Commission has operationalized these broad ideas about structural reform can be found in the country specific recommendations (CSRs) for each country in the last several years. A list of recommended reforms was helpfully summarized by Vice President Dombrovskis:

At national level, structural reform encompasses a broad set of measures, such as labour market reform; upskilling and re-skilling working people of all ages so that their profiles fit the jobs on offer; shifting the tax burden away from labour, especially low paid labour; ensuring long term sustainability of social and pension systems; boosting investment in R\&D, with an eye on both the quantity and quality; and improving the governance and effectiveness of our public services. ${ }^{40}$

Many elements on this list were present even before the crisis. Labor market reform still figures in many of the CSRs, and often focuses on reducing protections for permanent workers, which is thought to create labor market segmentation, in other words a sharp division between workers with permanent and workers with precarious contracts. Increased protections for workers are also believed to be problematic from the perspective of job creation. ${ }^{41}$ The Commission often still uses the language of "rigidities" in the labor markets to describe labor protections. ${ }^{42}$ It also continues to look suspiciously at minimum wage regulations, as potentially increasing workers' reservation wages and therefore their willingness to take up new jobs. ${ }^{43}$

Other elements such as the improvement of governance have made an appearance after the crisis and now regularly include items that fall well beyond the EU's competences such as taxation and judicial reform. The evaluation of governance now reads like an International Monetary Fund assessment in that it leaves out very little outside of the scope

Concept of 'Flexicurity': A New Approach to Regulating Employment and Labour Markets," European Review of Labour and Research 10, no. 2 (2004): 166-86.

${ }^{40}$ Valdis Dombrovskis, European Commission Vice-President, Speech at the Conference on Structural Reforms to Encourage Investment and Growth (March 3, 2017), https://ec.europa.eu/commission/commissioners/2014-2019/dombrovskis/announcements/vp-dombrovskisspeech-conference-structural-reforms-encourage-investment-and-growth_en.

${ }^{41}$ Commission Annual Growth Survey 2017, COM (2016) 725 final (November 16, 2016), 10 ("Those Member States that pursued comprehensive labour market and social protection reforms prior to the crisis have been better able to support employment and preserve fairness during the economic downturn. Such reforms encompass flexible and reliable contractual arrangements that promote labour market transitions and avoid a two-tier labour market").

${ }^{42}$ Commission Recommendation for a Council Recommendation on the 2017 National Reform Programme of Portugal and Delivering a Council Opinion on the 2017 Stability Programme of Portugal, COM (2017) 521 final (May 22, 2017), 3-5.

${ }^{43}$ Commission Recommendation for a Council Recommendation, COM (2017) 521 final, 6 (acknowledging the benefits of the minimum wage for the purposes of avoiding in-work poverty, but emphasizing the risks entailed for the low-skilled); Commission Recommendation for a Council Recommendation on the 2017 National Reform Programme of France and Delivering a Council Opinion on the 2017 Stability Programme of France, COM (2017) 509 final (May 22, 2017), 6 ("in the current context of high unemployment, there are risks that the cost of labour at the minimum wage hampers employment opportunities for low skilled people"). 
of desirable reform. While there is very little that can be done at EU level to induce countries to comply with recommendations that fall beyond the macroeconomic imbalance procedure, the Commission has created a new "carrot" for countries undertaking such reforms in the provision of technical support through the newly created Structural Reforms Support Service. ${ }^{44}$

\section{Preliminary Observations on "Structural Reforms 2.0"}

The Commission's recommendations for the types of reforms needed by Member States suggest that it has moved away from the emergency emphasis on quick adjustments via labor cost cuts and towards a broader idea about what kinds of reforms would be conducive to growth. Despite the Commission's repeated declarations about how there is no such thing as a 'one-size-fits-all' model, what emerges from the post-crisis literature it has produced is a very consistent emphasis on transforming every European country into an outward-looking, export-based economy. In addition, the Commission has a checklist of reforms that will be needed to achieve this result. That checklist continues to revolve around items that were already in the Commission's recommendations even before the crisis struck, namely, the deepening of the single market through liberalization of labor, service, and product markets, along with the transformation of European welfare regimes from factors of labor inactivity, to factors of labor activation.

In other words, a belief in liberalizing markets as an engine of growth in and of itself is still very much present in the Commission's recommendations, despite acknowledgment that said processes did not produce the desired upward "convergence" of European economies, except briefly through the operation of the credit bubble. A newly acquired emphasis on turning countries into globally competitive export engines begs the question of how exactly this will be achieved, given the truly gaping chasms in productive capacities between the different Member States and the traditional reliance of debtor and creditor states within the EU on trade between themselves as an engine for growth.

What seems to have changed through the crisis years is the list of areas that can be included in the broad category of structural reforms. The experience of crisis management seems to have expanded the checklist of reforms considerably. The Commission now regularly delves deeply into tax and social security regimes in its yearly recommendations, as well as into the catch-all category of the efficiency of public administration, which includes anything from judicial reform to using generic drugs to cut expenses in public health systems to improving the connections between educational systems and industry. This might be why the Commission insists that there is no one-size-fits-all model in its recommendations. Every country has a different mix of items on the checklist that need urgent action so each CSR includes different actionable items. It is still true, however, that the big picture is one of the Commission pushing Member States to adopt reforms that it thinks will allow them to become export-based economies, hopefully of high-tech product and services.

\footnotetext{
${ }^{44}$ See supra note 19.
} 
The other big difference between early post-crisis recommendations and more recent ones is the increased emphasis on the social aspects of the economy. The Juncker Commission prominently advertises the inclusion of social fairness as a goal of the economic convergence process, talking more broadly about "economic and social divergence" as a problem. ${ }^{45}$ It also touts the inclusion of social indicators in the yearly monitoring process of the European Semester as an indication that the EU now puts economic considerations on par with social ones. ${ }^{46}$ Some academic observers have taken these developments as an indication of the flexibility of the European Semester as an economic governance tool that is able to accommodate goals of economic adjustment and growth with more social goals of ensuring social fairness in growth (or in crisis). ${ }^{47}$

This warrants a few preliminary observations. The first one is that the flexibility of the European Semester can go both directions and it still quite early to make a judgment about whether the inclusion of "social" language is, in fact, a step forward, a step backward, or none of the above for those who care about the concept of a Social Europe. This is partly because much depends on what will happen next in the rest of the governance structure of the EMU. It may very well be that the Commission aspires to a deepening of the EMU that includes redistribution at EU level-, some proto EU-level welfare state. However, the politics of the Member States currently make this a highly unlikely event in the short to middle term. If it turns out to be true that all we can see in the next several years is management of an incomplete EMU, which by definition necessitates fiscal prudence and a switch to export-led growth for all Member States, without the capacity for more EUlevel redistribution, then the emphasis on the "social" in the European Semester is likely to serve the purpose of merely ensuring that "economic and social priorities are sustainable and work hand in hand." 48 In other words, the emphasis here is on the sustainability of the welfare regimes given the needs for fiscal prudence in the face of structural adjustment of productive models.

This emphasis on sustainability in turn will mean countries will be pressured to converge towards flexible welfare models that emphasize adaptability of workers to changing circumstances and the provision of minimum standards to the neediest. While these may very well be worthy goals for a welfare regime to achieve, they entail highly contested political values, which cannot merely be adopted under the guise of technical necessity but need to be negotiated between the stakeholders at national level. One could argue that since Member States have already agreed to the euro, what its management necessitates should also be considered democratically legitimate. However, that would be a highly formalist and counterproductive approach to the problem, risking even worse backlash from various populist movements around the EU. While the European Semester has produced very mixed results on Member State compliance, the Commission is working diligently to develop not only the substantive ideas about what constitutes desirable reform

${ }^{45}$ Commission Reflection Paper, COM (2017) 291, 12.

${ }^{46}$ Commission Reflection Paper, 33.

${ }^{47}$ Amy Verdun and Jonathan Zeitlin, "Introduction: The European Semester as a New Architecture of EU Socioeconomic Governance in Theory and Practice," Journal of European Public Policy 25, no. 2 (2018): 144 ("Semester provides a workable, if still imperfect framework for integrating EU social and economic policy co-ordination, without sacrificing the objectives of either process").

${ }^{48}$ Commission Reflection Paper, COM (2017) 291, 10. 
in these fields, but also the tools necessary to gradually increase its capacity for enforcement.

The Commission's emphasis on what it considers an appropriate tax regime for properties is just one example of this newly acquired substantive "know-how" on structural reforms. Since the crisis, the Commission has been recommending a switch from transaction taxes on property, to recurrent property taxes. This made a first appearance in the Greek program, where the Troika, i.e. the Commission, the European Central Bank, and the International Monetary Fund, noted that the transaction tax on property affected labor mobility. The link is as follows: one-time transaction taxes on property make property more affordable, indeed Greece has one of the highest home ownership rates in Europe even after the crisis. People who own property are less likely to pick up and leave in order to go look for a new job elsewhere. In other words, owning property increases the reservation wage for the unemployed and decreases labor mobility. Therefore less home ownership is a worthy goal for reform in the case of Greece because it would improve labor mobility and therefore decrease unemployment rates. This is an astonishing proposal on the part of the institutions formerly known as the Troika, especially since at the time, Greece's welfare regime had very little capacity to deal with the negative effects of the crisis and home ownership functioned as a social stabilizer in the absence of welfare rights. ${ }^{49}$

The Commission's theoretical commitment to recurrent property taxes as a more efficient tool is recently evident in the Commission's Staff Working Paper on Spain's 2017 Country Report. The authors once again emphasize that recurrent property taxes "allow a more efficient allocation of assets, as well as higher labour mobility." 50 The same recommendation can be found in Sweden's 2017 CSRs, with the purpose of decreasing the levels of household indebtedness, presumably because fewer people would even try to buy with recurrent property taxes. ${ }^{51}$ One can find the same recommendation in Austria and Ireland's CSRs as well, this time with the reasoning that it is a good way to increase tax revenue. $^{52}$

The point here is not that recurrent property taxes are wrong, or inefficient or undesirable. Rather the point is that they have now started to figure in the Commission's recommendations regularly, and regardless of the country's type of welfare regime. In the

\footnotetext{
${ }^{49}$ Georgios Symeonidis et al., "Comparative Analysis of Poverty in Greece Versus Richer European Countries in the Debt-Crisis Era." Working Paper no. 712, Luxembourg Income Study, August 2017, 15 ("higher owned housing percentages for pensioners in Greece versus [other] countries seems to be one of the few alleviating factors in the lives of this group in the current crisis").

${ }^{50}$ Commission Staff Working Document: Country Report Spain 2017, SWD (2017) 74 final (February 22, 2017), 24.

${ }^{51}$ Commission Recommendation for a Council Recommendation on the 2017 National Reform Programme of Sweden and Delivering a Council Opinion on the 2017 Convergence Programme of Sweden, COM (2017) 526 final (May 22, 2017), 5.

${ }^{52}$ Commission Recommendation for a Council Recommendation on the 2017 National Reform Programme of Austria and Delivering a Council Opinion on the 2017 Stability Programme of Austria, COM (2017) 519 final (May 22, 2017), 5; Commission Recommendation for a Council Recommendation on the 2017 National Reform Programme of Ireland and Delivering a Council Opinion on the 2017 Stability Programme of Ireland, COM (2017) 507 final (May 22, 2017), 5 [hereinafter Recommendation for Ireland].
} 
case of Greece, which belongs to the Mediterranean style of welfarism, in which the family internalizes much of the cost of unemployment and other forms of economic dependency, high levels of debt-free home ownership allowed the country to weather a dramatic drop in its GDP with less homelessness than would otherwise have been possible. The road through which recurrent property taxes lead to more labor mobility per the creditors plans is through the eventual loss of home ownership by people who can no longer foot the tax bill, which in turn will naturally lead to better takeup of available low-paying jobs. In an economic environment that is still dire, moving forward with the recurrent property tax without the jobs waiting for the newly dispossessed is a risky gamble. In the case of Sweden, the recurrent property tax is suggested as a means of disincentivizing people from taking up mortgages. It is an entirely different context, in which the measure does not risk causing social harm, because the economic conditions are entirely different and the background welfare regime is Scandinavian-style welfarism that provides more than the minimum to more than the neediest. In the cases of Austria and Ireland, the measure is recommended as a better way to raise tax revenue, without any discussion at all of the potential unintended social consequences. In all cases, these measures, with huge distributional consequences for different groups of stakeholders are proposed as merely technical improvements on "governance," without much consideration for the kind of democratic legitimation necessary for their adoption.

Other examples include the Commission's ideas about how to incentivize female labor participation. Those include providing full-day daycares and affordable childcare options, which are regularly included in the recommendations for countries showing low levels of female participation. ${ }^{53}$ But they also include more contested measures such as undoing the tax disincentives for the second wage earner to take up a job, when for example, the tax code provides for free health care insurance of a homemaker. In its 2017 recommendations to Germany, the Commission notes that free health care for a homemaker discourages her from taking up a job or increasing her hours worked in a part-time job. ${ }^{54}$ This is another example of a structural reform that is suggested on the basis of its importance for labor market participation, but it entails a very deep restructuring of the Member State's welfare regime under the guise of a technical recommendation from an institution that now declares it cares equally about economic and social goals of convergence, and is taking steps to supervise both equally.

It is worth mentioning that the 2015 Greek Memorandum of Understanding (MoU) repeatedly refers to reforming the Greek labor regime and welfare system according to "EU best practices." This is further indication that the elaboration of the conditionality for indebted countries has served as a kind of laboratory in which the Commission has worked out its ideas about what counts as an EU best practice. In its section on a Greek "growth strategy" the MoU refers to structural reforms according to "European best practices" right before it describes how major assets should be privatized for more efficient use of

\footnotetext{
${ }^{53}$ Recommendation for Ireland, COM (2017) 507 final, 6.

${ }^{54}$ Commission Recommendation for a Council Recommendation on the 2017 National Reform Programme of Germany and delivering a Council opinion on the 2017 Stability Programme of Germany, COM (2017) 505 final (May 22, 2017), 6.
} 
resources. ${ }^{55}$ Does the Commission as part of the institutions managing the Greek loan conditionality ascribe to privatization of public assets as a European best practice? It is unclear perhaps, but worrisome nonetheless in its presentation as a merely technocratic measure for better fiscal governance. If Greece achieves a restructuring of this magnitude in the midst of dire economic circumstances and without extra funding for the achievement of this goal, that is probably good news for the Commission, which will most likely have to push for similar reforms everywhere else, without the kind of spending capacity at EU level that would allow a sweetening of the pill.

As far as Greece's reform of its welfare regime goes, the MoU is unequivocal. There needs to be a fair sharing of the burdens of adjustment and that means creating a true safety net, which is in turn defined as attending to the needs of the poorest and the neediest. ${ }^{56}$ The MoU specifically mentions that this type of welfare regime would be in line with EU best practices. If the idea is that a welfare regime that attends to the needs only of the neediest is the goal for everyone, then we are again talking about a deep transformation of many welfare regimes around Europe, whether those are of the universalist or continental variant, both of which typically have included a certain level of de-commodification as their goal. ${ }^{57}$ In other words, the welfare regime encapsulated in the MoU is, following EspingAndersen's categorization, in the liberal mold, which requires citizens to turn to the market and commodify their labor in order to satisfy their basic needs, unless they fall in specific categories of extreme need or incapacity. A transformation of the Greek regime from the familialist provision of welfare to a minimum state-provided safety net for the neediest might prove to be a good thing — even though that's also subject to debate — or at the very least something that many citizens will experience as an improvement over their prior situation. The de-commodification push in Scandinavian and continental regimes, however, is a different story, and probably not a move that is going to be well received. In all cases, we are talking about deep, extremely political transformations that are presented as a 'best practice' through a process in which the European Commission is an important actor. Even a cursory review of the CSRs shows that the Commission has put its years of managing debtor conditionality to use in developing a substantive body of reforms it considers desirable for every Member State.

\footnotetext{
${ }^{55}$ Memorandum of Understanding Between the European Commission Acting on Behalf of the European Stability Mechanism and the Hellenic Republic and the Bank of Greece, 2 ("Greece will design and implement a wide range of structural reforms that not only ensure full compliance with EU requirements, but which also aim at achieving European best practices. The authorities will continue to implement an ambitious privatisation programme, and a new independent Privatisation and Investment Fund (HCAP) has been established supporting a more efficient use of resources").

${ }^{56}$ Memorandum of Understanding, 18 ("A fairer society will require that Greece improves the design of its welfare system in line with EU best practices, so that there is a genuine social safety net which targets scarce resources to those in most need").

${ }^{57}$ Esping-Andersen famously categorized welfare regimes into three ideal types; the universalist (like Sweden and other Scandinavian countries), the corporatist (like Germany) and the liberal (like the U.S.). Each regime entails different degrees of de-commodification and de-familialization. The concept of decommodification measures how much a state allows its citizens to be free from the pressure to sell their labor in the market in order to satisfy basic needs. De-familialization measures the degree to which a welfare regime allows individuals to be free from personal care obligations to other members of their family. See generally Gøsta Esping-Anderson, The Three Worlds of Welfare Capitalism (Cambridge: Polity Press, 1990).
} 
This seems to be true even in domains that would seem to fall well outside of the European institutions' purview such as the functioning of a Member State's judicial regime. During the process of monitoring the conditionality of Greece's latest loan - from the ESM this time - the Commission required Greece to create a "monitoring mechanism" for financial crimes, "including notably corruption and money laundering cases, with the objective to build a credible track-record of prosecuting and sanctioning such crimes." 58 While any state might want to improve its record on corruption, a framework of European governance in which the national executive branch is urged to put pressure on its judiciary in order to satisfy the conditions that will lead to the disbursement of money from its European creditors, is politically problematic regardless what one may think of the substance. Lest someone think that this is Greek exceptionalism again, in Portugal's 2017 CSRs, the Commission commends the country's efforts in the direction of fighting corruption through the judicial system. ${ }^{59}$ Nonetheless, it notes that "it remains to be seen whether [the improvements in numbers of prosecutions in corruption cases] will be reflected by improvements in final conviction rates. ${ }^{60}$ In other words, the Commission is seen as taking a position on the substantive outcomes of judicial cases pending in front of the independent judiciary of a sovereign Member State. Tone deafness to political sensibilities is arguably another part of the Commission know-how that sometimes seems to carry over to the regular European Semester process from bailout program management.

\section{Why do CSRs Matter Anyway?}

A plausible objection to these preliminary observations is that none of this really matters given that the preliminary empirical research on the effectiveness of the European Semester shows mixed results at best, and depends largely on the uptake of the proposed reforms by national actors. ${ }^{61}$ In other words, none of these critiques are really significant, if Member States can refuse to comply and if, in the end, it all boils down to national-level actors making decisions about which reforms they are or are not going to push through.

First, one should note that the empirical evidence so far mostly comes from a study of the situation before the financial penalty against non-compliance had ever been used by the Commission. Second, the data on effectiveness pre-dates the adoption of Regulation 1303/2013, which gives the Commission the possibility of conditioning the disbursement of structural funds to Member States on their compliance with CSRs.

With respect to the first point, on the Commission's recommendation, the Council adopted a financial penalty against Spain for a misrepresentation of regional statistics by

\footnotetext{
${ }^{58}$ Greece: Technical Memorandum of Understanding Accompanying the MoU of the ESM Programme (March 2018), 45, https://ec.europa.eu/info/sites/info/files/economy-finance/tmu_3rd_review.pdf.

${ }^{59}$ See Commission Recommendation for a Council Recommendation, COM (2017) 521 final, 8.

${ }^{60}$ Commission Recommendation for a Council Recommendation, 8.

${ }^{61}$ Zsolt Darvas and Álvaro Leandro, "The Limitations of Policy Coordination in the Euro Area Under the European Semester," Bruegel Policy Contribution 2015/19, November 2015; Hallerberg et al., "How Effective and Legitimate is the European Semester?." For an overview of the relevant literature see Verdun and Zeitlin, "Introduction: The European Semester as a New Architecture."
} 
Valencia in July 2015 as part of the Excessive Deficit Procedure (EDP). ${ }^{62}$ The fine was imposed on a country for a misrepresentation by one of its regions so it was not a penalty based on the Macroeconomic Imbalance Procedure (MIP), but it does set a precedent. Despite the fact that this fine was set in the EDP rather than the MIP process, research shows that some of the actors involved in the European Semester, namely Commission officials and state representatives in the Council, may see the imposition of this fine as a precedent for the MIP as well. ${ }^{63}$ This seems to be why state officials through the Council then proceeded to object to the Commission's proposal to include a number of "social" indicators in the regular scoreboard that serves as the baseline for assessing macroeconomic imbalances in the European Semester. ${ }^{64}$ State actors did not want the intrusive process of multilateral surveillance to go too deeply into employment and labor policy. ${ }^{65}$ The Commission, however, proceeded to do it, "because it is our choice" as one official apparently put it. ${ }^{66}$ In the mind of the actors directly involved then, the possibility of a fine to enforce CSRs even in areas such as employment and social indicators is not science fiction but a real possibility.

On the second point, Regulation $1303 / 2013$ gives the Commission the possibility to condition disbursement of structural funds on compliance with CSRs. ${ }^{67}$ In other words, this Regulation created a possibility for inserting a process of conditionality much like the one creditor countries were subject to as part of the loan agreements. The Commission refers to this possibility in its papers somewhat euphemistically ("closer linkage between national

\footnotetext{
${ }^{62}$ European Council Press Release 581/15, Deficit Data in Valencia: Spain Fined for Misreporting (July 13, 2015).

${ }^{63}$ See James D. Savage, "Enforcing the European Semester: The Politics of Asymmetric Information in the Excessive Deficit and Macroeconomic Imbalance Procedure," Draft paper, 24, https://ecpr.eu/Filestore/PaperProposal/0b987b53-9c28-493a-acb1-8018badb6e48.pdf.

${ }^{64}$ Savage, "Enforcing the European Semester," 24 ("The Council, meanwhile, rejected the promotion of social indicators because they potentially exposed the member states' economic and social policies to Commission programmatic intervention and fines").

${ }^{65}$ Savage, "Enforcing the European Semester," 21-22 ("What they don't want is to take the risk to be fined for social issues"). The version of this draft paper that was published does not include the story of how the social indicators were adopted by the Commission see James D. Savage and David Howarth, "Enforcing the European Semester: The Politics of Asymmetric Information in the Excessive Deficit and Macroeconomic Imbalance Procedures," Journal of European Public Policy 25, no. 2 (2018): 212-30.

${ }^{66}$ Savage, "Enforcing the European Semester," 22. The European Parliament recently published a study about the mainstreaming of employment and social indicators into macroeconomic surveillance. The trade unions and anti-poverty NGOs consulted expressed reservations about the process. They underlined that the role of social indicators in the Semester is "ambiguous" and complained that their consultation was very limited. See European Parliament, Directorate-General for Internal Policies, Mainstreaming Employment and Social Indicators into Macroeconomic Surveillance, IP/A/EMPL/2014-18 (February 2016), 44. The European Trade Union Confederation went as far as to say that the structural reforms promoted through the European Semester have undermined the European social model. See European Trade Union Confederation, "The ETUC Position on the Annual Growth Survey 2016-for a Europe that Works for Workers and Citizens," October 28-29, 2015, https://www.etuc.org/sites/default/files/document/files/en-etuc-position-ags.pdf /.

${ }^{67}$ European Parliament and Council Regulation 1303/2013, Laying Down Common Provisions on the European Regional Development Fund, the European Social Fund, the Cohesion Fund, the European Agricultural Fund for Rural Development and the European Maritime and Fisheries Fund and Laying Down General Provisions on the European Regional Development Fund, the European Social Fund, the Cohesion Fund and the European Maritime and Fisheries Fund and repealing Council Regulation (EC) No. 1083/2006, 2013 O.J. (L 347) 320.
} 
reforms and existing EU funding") but since 2016 CSRs all include a separate article that reminds Member States that Article 23 of Regulation 1303/2013 gives the Commission this prerogative. Admittedly, it is politically hard to envisage such an imposition even though a partial precedent has been set on the specific issue of misreported statistics. The literature so far cautions that ex-post conditionality, that is the proposal to suspend funding until a fiscal or macroeconomic imbalance has been corrected, will be almost impossible to properly monitor and enforce, while it will also cause tensions between Member States. ${ }^{68}$ However, another reason to think that cohesion fund conditionality might someday become reality, is that its biggest proponent seems to be the German government, which is the biggest creditor in the context of an incomplete monetary union. ${ }^{69}$

In summary, the objection that weak country-compliance renders some of the policy reforms in the CSRs irrelevant is becoming less sustainable in the face of the new enforcement mechanisms in place and the suggestion that they could be used. The probability of their use becomes even greater in a scenario where the EMU continues to lack the necessary tools to avert another crisis, such as a full banking union. Should another big crisis come along, the disbursement of ESM funds to Member States will surely be conditioned on compliance with suggested reforms; the content of these reforms will surely be influenced by the prior stages of crisis management.

It is interesting to compare with developments in the area of rule-of-law conditionality. As Kim Scheppele's and Dan Kelemen's contribution to this book highlights, various proposals for imposing rule-of-law conditionality on structural fund access have been put forth in the cases of Hungary and Poland, but without success. ${ }^{70}$ Both of these countries have adopted a number of reforms that reinforce autocratic power in the executive arm. The Commission seems to be split on the desirability of such conditionality with President Juncker opposing it as "poison for the European continent." "71 From the perspective of the perceived legitimacy of the Union, a situation in which structural reforms can be imposed as conditionality for the purposes of macroeconomic and budgetary discipline but without the equivalent conditionality in the case of human rights violations, would be very problematic.

This chapter's analysis of developments in the European Semester as potentially negative for Social Europe stands somewhat at odds with recent research by Jonathan Zeitlin and Bart Vanhercke. ${ }^{72}$ Zeitlin and Vanhercke observe that developments over the

\footnotetext{
${ }^{68}$ Cinzia Alcidi and Daniel Gros, "How to Strengthen the European Semester?," Centre for European Political Studies Research Report no. 2017/15, December 2017, 18-20; Robin Huguenot-Noël et al., "Can the EU Structural Funds Reconcile Growth, Solidarity and Stability Objectives? A Study on the Role of Conditionalities in Spurring Structural Reforms and Reducing Macroeconomic Imbalances," Issue Paper no. 83, European Policy Centre, October 2017, 16.

${ }^{69}$ Alcidi and Gros, "How to Strengthen the European Semester?," 18-20; Huguenot-Noël et al., "Can the EU Structural Funds Reconcile Growth, Solidarity and Stability Objectives?," 16.

${ }^{70}$ Kim Lane Scheppele and R. Daniel Kelemen, "Defending Democracy in EU Member States: Beyond Article 7 TEU," this volume, 17-21.

${ }^{71}$ Scheppele and Kelemen, "Defending Democracy in EU Member States," 20.

${ }^{72}$ Jonathan Zeitlin and Bart Vanhercke, "Socializing the European Semester: EU Social and Economic Policy Co-ordination in Crisis and Beyond," Journal of European Public Policy 25, no. 2 (2018): 149-74.
} 
last several years have, if anything, 'socialized' the European Semester at the initiative of actors who are working on behalf of Social Europe. Their extensive surveys document the impressive expansion of CSRs to include social objectives and further show that this outcome was the result of collaborative processes of different actors within the Commission and different committees in the Council. In this respect, it is worth noting that there is at least some indication that there was a certain degree of conflict in the process of "socializing" the European Semester; resistance came from Member State reluctance to allow the Commission to intrusively monitor the employment and social fields. ${ }^{73}$

Moreover, even though the process might have become somewhat more inclusive, it is still true that the model of Social Europe that seems to predominate in the European Semester is one where the market is understood as the main motor for growth and prosperity and where social policy reforms are geared towards creating adaptable, employable workers who will turn to employment for meeting even their basic needs. As Mark Dawson observes, even social officials in the EU institutional structure seem to subscribe to a version of social policy as first and foremost a production factor rather than a tool for creating lives that are not entirely market dependent - an astonishing development that narrows the scope of Social Europe as previously understood. ${ }^{74}$

This potential narrowing of the meaning of Social Europe reflects a broader EU institutional trend and comes about through a process mostly concentrated in the EU executive arm. As noted in Renaud Dehousse's chapter, one of the hallmarks of the EU's recent crises has been the empowerment of technocratic actors in the process of norm production. ${ }^{75}$ Even if the executive itself is now subject to constraints coming from a multilateral surveillance process of relevant experts at national and EU level, it is not a process that seriously engages democratic deliberation. Verdun and Zeitlin document the increased participation of national representatives in the Council in the formulation of the CSRs and note that "much of the real debate" about the recommendations takes place in the dialogue between the Commission and the Council's committees. ${ }^{76}$ They then take this development as an indication that "peer review by expert officials enhances rather than restricts the scope for democratic debate." 77 Beyond the problems with equating the dialogue between national and supranational experts with democratic deliberation, this position overlooks the potential for the process of multilateral deliberation to become more coercive. Note that when the moment came for deciding whether social indicators were going to be included in the European Semester, national representatives in the Council opposed it, and the Commission proceeded to include them anyway, knowing very well that national representatives opposed it because they did not want close surveillance or potential fines imposed in the process. ${ }^{78}$

\footnotetext{
73 Savage, "Enforcing the European Semester."

${ }^{74}$ Mark Dawson, "New Governance and the Displacement of Social Europe: The Case of the European Semester," European Constitutional Law Review 14, no. 1 (2018): 206-07.

${ }^{75}$ Renaud Dehousse, "The Euro Crisis and Beyond: The Transformation of the European Political System," this volume.

${ }^{76}$ Verdun and Zeitlin, "Introduction: The European Semester as a New Architecture," 145.

${ }^{77}$ Verdun and Zeitlin, 145-46.

${ }^{78}$ Savage, "Enforcing the European Semester."
} 
A last reason one might downplay the potentially negative effect of "the social" in CSRs is the launching of a "European Pillar of Social Rights" by the Commission in April 2017. ${ }^{79}$ However, on this topic, I am in agreement with Sacha Garben's estimation that while there are many promising aspects to the Social Pillar, it does not address the fundamental issue of the "displacement of the national and European legislative process in the two areas where the most important social decisions have been made in the EU during the past decade: the internal market and European economic governance." 80 Yet another illustration of the displacement of legislative politics in the social domain can be found in this chapter. The carryover of expertise from the loan agreements to the European Semester, with the identification of "EU best practices," demonstrates how policy reforms with deep implications for welfare states are elaborated in the domain of economic governance, through the input of economic expertise. At the current stage, the multilateral surveillance mechanism incorporating a dialogue between national and supranational experts on the contested issues seems to have produced a renewed emphasis on Social Europe. In the process, however, the very concept has been redefined in a way that excludes options, a choice with profound consequences that instead should be decided through a genuine democratic engagement at the national and supranational levels.

\footnotetext{
${ }^{79}$ Commission Recommendation on the European Pillar of Social Rights, C (2017) 2600 final (April 26, 2017); Communication from the Commission, Establishing a European Pillar of Social Rights, COM (2017) 250 final (April 26, 2017); European Parliament, European Commission, and Council of the European Union, European Pillar of Social Rights, November 17, 2017, https://ec.europa.eu/commission/sites/beta-political/files/social-summit-european-pillar-social-rightsbooklet_en.pdf.

${ }^{80}$ Sacha Garben, "The Constitutional (Im)balance Between 'the Market' and 'the Social' in the European Union,” European Constitutional Law Review 13, no. 1 (2017): 23-61.
} 